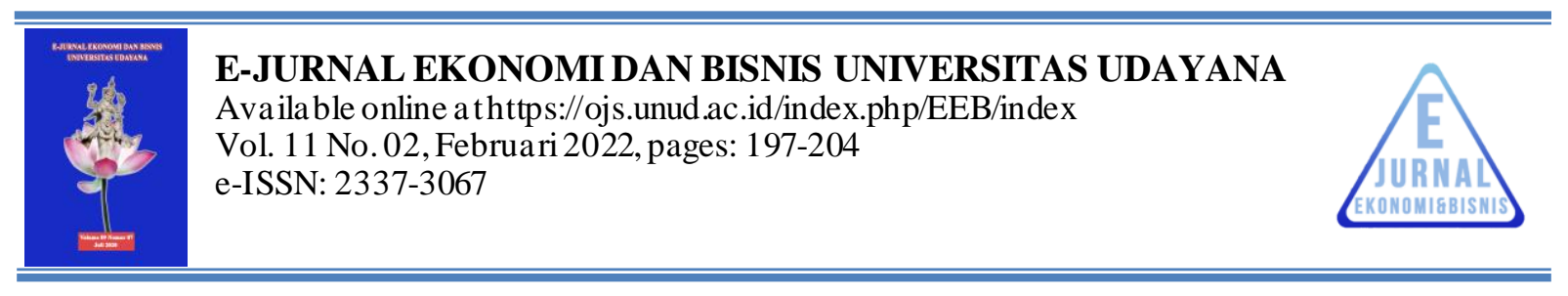

\title{
PERSEPSI PESERTA PANDEMIC INCUBATION PROGRAM TERHADAP KEBERLANJUTAN UMKM DI KOTA DENPASAR
}

Ni Wayan Purnami Rusadi ${ }^{1}$ Ni Wayan Dian Irmayani ${ }^{2}$ Gede Bagus Dera Setiawan ${ }^{3}$

\begin{tabular}{ll}
\hline \hline Article history: & Abstract \\
\hline
\end{tabular}

Submitted: 9 Agustus 2021

Revised: 13 September 2021

Accepted: 28 September 2021

\section{Keywords:}

Perception;

Pandemic;

Incubation;

Program;

MSMEs;

\section{Kata Kunci:}

Persepsi;

Pandemic;

Incubation;

Program;

UMKM;

\section{Koresponding:}

Politeknik Nasional Denpasar,

Bali, Indonesial

Email:

dianirmayani51@gmail.com
The high number of workers who wereeconomically affected by the Pandemic in Denpasar City prompted the Denpasar City Government through the Denpasar CityTourism Office to hold a Pandemic In cubation Program. The purpose of this study was to determine the effect of the Participants' Perceptions of the Pandemic Incubation Program on the Sustainability of MSEs in Denpasar City. The method used in this rese arch is quantitative descriptive analysis, using the SEM-PLS analysis method. The sample in this study amounted to 105 participants who were selected purposively with the criteria of participants who took the PIP from start to finish for two months. PIP participants' perceptions and participants' perceptions of the sustainability of micro, small and medium enterprises in Denpasar Cityare in the good category. The results of the an alys is also show that PIP has a positive and significant relationship to the continuation of micro, small andmedium enterprises in Denpasar City.

\begin{tabular}{|c|}
\hline Abstrak \\
\hline $\begin{array}{l}\text { Tingginya angka tenaga kerja yang terdampak secara ekonomi pa da } \\
\text { Pandemidi Kota Denpasar mendorong Pemerintah Kota Denpasar melalui } \\
\text { Dinas Pa riwisa ta Kota Denpasarmenggelar Pandemic Incubation Program. } \\
\text { Tujuan penelitian ini adalahuntuk mengetahui pengaruh Persepsi Peserta } \\
\text { Pandemic Incubation Program Terhadap Keb erlanjutan Um km Di Kota } \\
\text { Denpasar. Metode yang digunakan dalam penelitian ini a dalah a nalisis } \\
\text { deskriptif kuantitatif, menggunakan metode analisis SEM-PLS. Sa mpel } \\
\text { dalam penelitian ini berjumlah } 104 \text { UMKM yang dipilih secara } \\
\text { nonprobabilitysampling yakni sampling kebetulan (insiden tal/accidental } \\
\text { sampling). Persepsi peserta PIP dan persepsi peserta terhadap keberlanjutan } \\
\text { usaha mikro, kecil dan menengah di Kota Denpasar termasuk dalam } \\
\text { kategori baik. Ha sil analisis juga menunjukkan bahwa PIP memiliki } \\
\text { hubungan yang positif dan signifikan terhadapkelanjutan usaha mikro, kecil } \\
\text { dan menengah di Kota Denpasar. }\end{array}$ \\
\hline
\end{tabular}

Politeknik Na sional Denpasar, Bali, Indonesia ${ }^{2,3}$ 


\section{PENDAHULUAN}

Corona Virus Disease 2019 (Covid-19) telah menyebabkan krisis global yang belum pernah terjadi sebelumnya dengan dampak yang sangat besar pada sistem politik, sosial, dan ekonomi hanya dalam waktu singkat (Carlsson-Szlezak, 2020). Pandemi Covid-19 memaksa semua pihak untuk merespon sertamemberikan tanggapan yang cepat dalam mengatasi pandemi ini. Peraturan Pemerintah Nomor 21 Tahun2020 tentang Pembatasan Sosial Berskala Besar Dalam Rangka Percepatan Penanganan Corona Virus Disease2019 yang ditetapkan oleh pemerintah Indonesiamemaksa masyarakat untuk mengurangi interaksidengan orang lain, mengurangi kunjungan ke tempatumum, dan menghindari kerumunan. Hal inidiperparah dengan adanya lockdown yang dilakukanoleh berbagai negara semenjak banyak kasus positif Covid-19 di negaranya (Somawati, 2020). Lockdownberarti suatu negara menutup perbatasannya agartidak ada orang yang masuk atau keluar dari negaranya (Gössling, 2020). Kebijakan ini menyebabkan berbagaiaktivitas di Indonesia khususnya dalam bidangperekonomian terhambat (Ahmad, 2020).

Pandemi Covid-19 yang terjadi saat ini tentunya mengakibatkan melemahnya berbagai sektor perekonomian di seluruh dunia termasuk di Bali dengan sektor pariwisata sebagai pendapatan utama masyarakat. Sektor pariwisata berkontribusi 78 persen terhadap perekonomian Bali. Sangat jauh dari sector pertanian yang hanya menyumbang 14,5 persen. Ketimpangan ini menyebabkan ketergantungan yang terlalu besar pada sektor pariwisata (Purwahita, 2021). Industri pariwisata adalah sektor yang paling terdampak dalam pandemi ini, terutama Bali (Arni Darmayanti ${ }^{1}$, Gede Budarsa ${ }^{2}$, 20221). Bali sebagai salah satu provinsi yang mengandalkan industri pariwisata dengan sekejap menjadi sepi pengunjung. Hingar bingar kehidupan malam di Kuta, hiruk pikuk wisatawan di Ubud, tari Kecak di Uluwatu seketika padam. Perekonomian Bali seolah ambruk diterjang virus yang tak kasat mata ini. LPEM FEB UI mencatat, tingkat okupansi atau hunian hotel di Bali mengalami penurunan drastis dari 63\% di bulan Desember 2019 menjadi 46\% di bulan Februari 2020 (LPEM-FEB-UI, 2020).

Dampak negatif penyebaran virus corona tak hanya dirasakan oleh masyarakat saja, tetapi juga dunia usaha baik skala kecil, menengah, maupun besar. Industri Pariwisata dan Perhotelan, Kondisi industri pariwisata yang biasanya saat ini berada di masa high season kini berubah drastis, di mana tempat-tempat wisata sepi bahkan pihak pengelola harus menutup dan menghentikan operasional layanannya. Penyebaran virus Corona ini memberi pukulan keras bagi kelompok masyarakat ini, karena mereka 'terpaksa' harus menghentikan kegiatan usahanya. Artinya, praktis pendapatan mereka berkurang bahkan tidak memiliki penghasilan sama sekali. Di saat mereka dalam posisi jobless tanpa penghasilan, mereka pun harus memenuhi kebutuhan untuk bisa melangsungkan kehidupannya (Rwa Jayantini dkk, 2020).

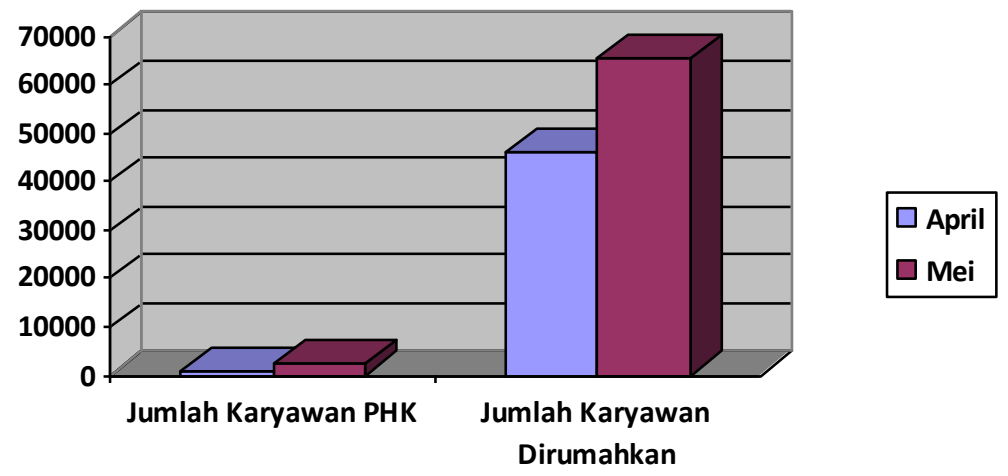

Sumber: Kompas.com, 2020

\section{Gambar 1. \\ GrafikJumlah Karyawan Tahun 2020}

Hingga 13 April 2020 jumlah karyawan yang di-PHK jumlahnya mencapai 800 orang dan ada 46.000 karyawan yang dirumahkan. Sebagian besar dari mereka adalah pegawai di sektor pariwisata seperti hotel dan restoran (Kompas.com, 2020). Seiring dengan semakin meningkatnya wabah corona, 
jumlah karyawan yang di-PHK semakin bertambah. Pada 12 Mei 2020 jumlahnya mencapai 2.189 orang, sedangkan karyawan yang dirumahkan sebanyak 65.594 orang (Merdeka.com, 2020). Tingginya angka tenaga kerja yang terdampak secara ekonomi pada Pandemi di Kota Denpasar mendorong Pemerintah Kota Denpasar melalui Dinas Pariwisata (DISPAR) Kota Denpasar menggelar Pandemic Incubation Program (PIP). Program ini diharapkan mampu menjadi solusi untuk mencari sumber pendapatan lain dengan membangun usaha mikro, kecil dan menengah. Berbagai upaya dilakukan oleh Pemerintah Kabupaten/Kota yang ada di Bali telah bergiat mengembangkan potensipotensi lokal untuk membuat wisatawan domestik maupun mancanegara tetap tertarik mengunjungi pulau dewata (Purwahita, 2021).

Pandemi Covid-19 berefek pada perekonomian Bali yang mengandalkan sektor pariwisata. Turunnya tingkat kunjungan wisatawan ke Bali berpengaruh terhadap pendapatan berbagai pekerja pariwisata (Arni Darmayanti ${ }^{1}$, Gede Budarsa ${ }^{2}$, 2021). Mereka harus berjuang untuk bertahan hidup di tengah kemelutnya perekonomian Bali. Pemerintah Kota Denpasar terus berupaya untuk mendukung pemulihan ekonomi di tengah pandemi saat ini. Meski wabah Covid-19 belum usai, inovasi guna mendukung pergerakan ekonomi terus dioptimalkan. Salah satunya dengan melaksanakan PIP ini bertujuan untuk memberikan stimulus produktif bagi masyarakat Kota Denpasar untuk memulai usaha, terutama bagi masyarakat yang terdampak pandemi Covid-19.

PIP merupakan program dari Pemerintah Kota Denpasar melalui Dinas Pariwisata Kota Denpasar yang berujuan untuk memberikan bantuan berupa stimulus produkti bagi masyarakat Kota Denpasar untuk memulai usaha, namun tidak menutup kemungkinan bagi para pelaku usaha juga mendapatkan bantuan stimulus tersebut berkaitan dengan keberlanjutan usaha mereka yang juga terdampak pandemi Covid-19.

Penelitian ini menjadi menarik di lakukan karena penelitian mengenai dampak pandemic covid 19 yang mengharuskan segala bisnis yang bergantung pada komunikasi tatap muka atau kedekatan fisik Ketika memproduksi suartu produk atau memberikan pelayanan menjadi sangat rentan terinveksi virus (megaartha 2021). Salah satu cara untuk membangkitkan perekonomian yaitu dengan adanya bantuan pemerintah baik dalam bentuk bantuan tunai ataupun regulasi kebijakan. Peraturan atau kebijakan yang telah ditetapkan oleh pemerintah tentu sangat berpengaruh terhadap segala sektor, termasuk perekonomian dan kehidupan sosial dalam masyarakat (Rwa Jayantini dkk, 2020).

Penelitian yang dilakukan (Hapsari Ardianti,) menyatakan bahwa peran pemerintah tidak berdapak sigifikan terhadap keberlanjutan UMKM. Penelitian menyatakan (Sirami Yanti, 2020) menyatakan bahwa pemerintah sangat beperan penting bagi keberlanjutan UMKM di daerah. Legalitas dan tatakelola sangat bergantung oleh kebijakan pemerintah daerah. Penelitian (2020. Rwa Jayantini) menyatakan bahwa pemerintah melalui peraturan atau kebijakan yang telah ditetapkan sangat berpengaruuh terhadap segala sector, termasuk sektor UMKM. Tujuan penelitian ini adalah untuk mengetahui pengaruh Persepsi Peserta Pandemic Incubation Program Terhadap Keberlanjutan Umkm Di Kota Denpasar.

Target peserta untuk program ini adalah sebanyak 1.700 orang dengan syarat memiliki KTP Kota Denpasar dengan masing - masing menerima bantuan dana sebesar Rp. 1.000.000,- dengan kategori penerima adalah masyarakat disabilitas dan masyarakat umum (https://covid19.denpasarkota.go.id/berita/read/26389). Dengan adanya stimulus yang diberikan oleh Pemerintah Kota Denpasar, diharapkan muncul ide - ide kreatif usaha mikro yang mungkin untuk dijalankan oleh peserta sebagai alternatif memperoleh penghasilan. Disamping itu, peserta juga akan diberikan motivasi tentang berwirausaha. Dalam program ini juga akan diadakan workshop untuk memberikan bekal pengetahuan mengenai teknis produksi atau operasional dari usaha yang akan digeluti. Pembagian kelompok didasarkan kepada bidang usaha yang dipilih/diminati, yaitu kuliner, fashion-garmen, kerajinan, perdagangan/reseller, IT, desain \& multimedia, pertanian dan jasa. Berdasarkan pembagian kelompok tersebut, narasumber juga dibagi menurut bidang - bidang pelaku/praktisi dari masing - masing bidang usaha. Praktisi/pelaku usaha tersebut akan memberikan sharing dari masing - masing bidang usaha dari sudut pandang yang berbeda. Selain memberikan materi tentang kewirausahaan dan sharing tentang usaha, peserta juga akan diberikan pelatihan tentang pemasaran/marketing. Materi pemasaran yang akan diberikan berupa workshop tentang social media marketing, desain dan foto produk, yang secara keseluruhan pendampingan akan diberikan selama tiga bulan untuk keseluruhan program. 
PIP merupakan sebuah upaya untuk mendukung pemulihan ekonomi lewat usaha rintisan masyarakat. Dimana, kegiatan ini dikemas melalui pemberian Bantuan Stimulus Produktif sebesar Rp. 1.000.000,-, dimana pada PIP tahun 2020, telah lolos sebanyak 2.700 penerima stimulus produktif ini. Kegiatan pendampingan ini diharapkan juga bisa memberikan kesempatan bagi para pekerja yang terdampak untuk memutar kembali roda ekonomi mereka dengan memulai usaha tanpa perlu bergantung kembali pada pekerjaan lama mereka karena hidup akan terus berjalan meski kehidupan saat ini sedang sulit. Penelitian terkait PIP ini diharapkan mampu untuk memberikan gambaran mengenai persepsi masyarakat terdampak Covid-19 tentang PIP di Kota Denpasar. Perkembangan pariwisata di masa pandemi, yang menyebabkan keterpurukan perlu segera ditangani oleh pemerintah dengan mengeluarkan kebijakan secara holistik dalam menangani situasi ini. Akibat dari jumlah tenaga kerja yang mengalami pengangguran tentu akan berakibat dalam peningkatan jumlah angka kemiskinan di Bali (Purwahita, 2021).

\section{METODE PENELITIAN}

Penelitian dilakukan di Kota Denpasar, dimana PIP dilakukan pada tahun 2020. Waktu penelitian dilakukan selama tiga bulan selama bulan April - Juli 2021 dikarenakan program PIP ini telah dilakukan pada tahun 2020 sehingga pelaksanaan PIP dapat dinilai dan dirasakan manfaatnya oleh pelaku UMKM. Analisis dimulai dari tim peneliti menyebarkan kuesioner secara online menggunakan google document ke pelaku usaha yang tergabung dalam PIP. Setelah data kuesioner terkumpul, dilakukan tabulasi data untuk menentukan persepsi pelaku usaha terhadap adanya PIP dan faktor - faktor yang mempengaruhi keberhasilan PIP terhadap pelaku UMKM di Kota Denpasar. Populasi penelitian ini adalah seluruh UMKM yang terdaftar pada PIP tahun 2020 yaitu sebanyak 2.700 UMKM (2021, Dera Setiawan). Teknik pengambilan sampel dalam penelitian ini adalah dengan menggunakan teknik nonprobability sampling, yaitu sampling kebetulan (insidental/accidental sampling). Menurut Sugiyono (2017), sampling insidental adalah teknik penentuan sampel berdasarkan kebetulan, yaitu siapa saja yang secara kebetulan/insidental bertemu dengan peneliti dapat digunakan sebagai sampel, bila dipandang orang yang kebetulan ditemui itu cocok sebagai sumber data. Oleh karena situasi pandemi dan metode penyebaran kuesioner yang dilakukan secara online, maka jumlah kuesioner yang kembali menjadi sampel penelitian, dimana sampel penelitian ditetapkan 104 UMKM sebagai sampel penelitian. Instrument penelitian yang digunakan dalam penelitian ini adalah kuesioner online menggunakan google document dengan ketentuan sebagai berikut: Jawaban (a) sangat baik, dengan perolehan skor 5, Jawaban (b) baik, dengan perolehan skor 4, Jawaban (c) cukup, dengan perolehan skor 3, Jawaban (d) kurang, dengan perolehan skor 2, dan Jawaban (e) sangat kurang, dengan perolehan skor 1

Dalam prosedur penelitian menggunakan uji validitas instrumen penelitian, yakni suatu ukuran yang menunjukan tingkat-tingkat kevalidan atau keabsahan suatu instrument. Ketentuan suatu instrumen dikatakan valid apabila memiliki koefisien korelasi Pearson Product Moment $(r)>0,3$ (Sugiyono, 2012). Sedangkan menurut Rianse \& Abdi (2012) teknis analisis yang digunakan adalah dengan mengkorelasikan antara skor item instrument dengan rumus Pearson Product Moment, dengan persamaan sebagai berikut:

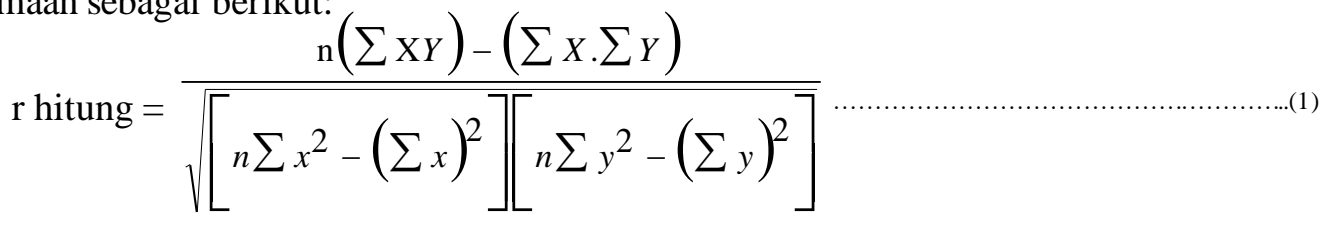

Keterangan :

$\mathrm{r}$ hitung $=$ koefisien korelasi

$\sum \mathrm{Xi}=$ Jumlah skor item

$\sum \mathrm{Yi} \quad=$ Jumlah skor total (seluruh item)

$\mathrm{n} \quad=$ Jumlah responden

Kaidah keputusan : (1) jika t-hitung $\leq \mathrm{t}$-tabel berarti tidak valid dan (2) jika t-hitung $>\mathrm{t}$-tabel berarti valid. Selain uji validitas, juga dilakukan uji reliabilitas yang menunjukan bahwa sesuatu 
instrument cukup dapat dipercaya untuk digunakan sebagai alat pengumpulan data karena instrument tersebut sudah baik. Menurut Siregar (2013) ada beberapa teknik yang digunakan untuk mengukur reliabilitas suatu instrument penelitian tergantung dari skala yang digunakan, salah satunya adalah teknik Alpa Cronbach. Teknik ini dapat digunakan untuk menentukan apakah suatu instrument penelitian reabel atau tidak, bila di jawab yang diberikan responden yang menginterpretasikan penilaian sikap. Kriteria suatu instrument penelitian dikatakan reabel dengan menggunakan teknik Alpa Cronbach, bila koefisien reliabilitas $(r 11)>0,6$. Rumus yang digunakan seperti diberikut ini:

$$
\mathrm{r} 11=\left(\frac{\mathrm{k}}{\mathrm{k}-1}\right)\left(1-\frac{\sum \sigma^{2} \mathrm{~b}}{\sigma^{2} \mathrm{t}}\right) \text {. }
$$

Keterangan :

$$
\begin{array}{ll}
\mathrm{r} 11 & =\text { Koefisien reliabilitas instrument } \\
\sum \sum_{02 \mathrm{~b}} & =\text { Jumlah varians butir } \\
\sigma 2 \mathrm{t} & =\text { Varians total } \\
\mathrm{k} & =\text { Jumlah butir pertanyaan }
\end{array}
$$

Analisis data menggunakan analisis deskriptif yang mana merupakan penelitian berdasarkan pada pengumpulan data. Pengumpulan data primer maupun data sekunder berdasarkan dokumentasi atau penelitian. Penilaian data untuk menyeleksi kategorisasi data primer atau data sekunder. Interpretasi data dilakukan untuk menafsirkan sejumlah data yang ditemui di lapangan. Kesimpulan dihasilkan berdasarkan generalisasi dari pernyataan-pernyataan tentang permasalahan.

Terdapat unsur utama dalam proses analisis data pada penulisan kualitatif yaitu: (1) Pengumpulan data; (2) Penilaian data; (3) Interprestasi data; dan (4) Menarik kesimpulan (Winarno, 2002). Berdasarkan unsur-unsur yang dikemukakan tersebut di atas, maka peneliti menjabarkan sebagai berikut: Pengumpulan data, dilakukan dengan teknik dokumentasi a tau penelitiankepustakaan un tuk memperoleh baik data primer maupun sekunder. Kemudian pen gamatan tentang kinerja organisasi a tau instansi. Terakhir dengan pelengkap wawancara dengan pihak-pihak yang berkompeten dalam hal-hal y ang berhubung an denga n masalah penelitian ini. Penila ian data, pada tahap ini masalahnya a dalah validitas dan obyektifitas sehingga perlu melakukan kategorisasi data primerdan sekunder dengan pencatatan serta m ered uksi data sekunder, kemudian diseleksi agar relevan dengan masalah penelitian. Interpre tasi da ta, y akni m emberikan penilaian (penafsiran), menjelaskan pola atau kategori serta mencari dan menggambarkan hubungan pengaruh antar berbagai konsep. Langkah ini dilakukan berdasarkan pemahaman intelektual dalam arti dibangun berdas ar penga matan empiris. Untuk ini, memerlukan seperangkat konsep yang telah tersusun, yang dalam penelitia $\mathrm{n}$ in i berupa teori-teori tentang kinerja organisasi publik. Menarik kesimpulan atau generalisa si, yaitu ditujukan untuk menjawab pertanyaan dalam permasalahan yang dirumuskan dengan melihat dasar analisis y a ng dila kukan, kemudian disusul dengan komentar terhadap hasil kesimpulan (Winarno, 2002).

Metode analisis data secara deskriptif dalam penelitian berfungsi mendiskripsikan variabelvariabel yang diteliti dan memberikan interprestasi sesuai tujuan penelitian. Indikator dari setiap variable Program PIP (X) dan Keberhasilan Usaha (Y) diukur menggunakan skala ordinal dengan rentang nilai 1 sampai 5. Menganalisis data dengan metode deskriptif berupa pembobotan data yang bertujuan memaknai (mengartikan) tingkat kepentingan dari masing-masing pertanyaan. Data yang diperoleh kemudian didistribusikan dalam kategori berbeda-beda. Penentuan kategori dilakukan berdasarkan kelas-kelas interval tertentu dengan menggunakan rumus di bawah ini:

$$
i=\frac{\text { Jarak }}{\text { Jumlah Kelas }}
$$

Keterangan :
i
Jarak : nilai skor tertinggi dikurangi nilai skor terendah
Jumlah Kelas : adalah jumlah kelas atau kategori yang ditentukan
Penilaian dalam penelitian ini memiliki nilai skor terendah 1, skor tertinggi 5 dan jumlah kategori adalah 5 maka, $\mathrm{i}=(5-1) / 5$ dengan hasil 0,80, Sehingga kategori pencapaian skor dijelaskan pada Tabel 1 sebagai berikut. 
Tabel 1.

Kategori Pencapaian Skor Indikator dan Variabel Penelitian

\begin{tabular}{lll}
\hline No & Pencapaian Skor & Kategori \\
\hline 1 & $1,00-1,80$ & SangatTidak Baik \\
2 & $1,81-2,60$ & Tidak Baik \\
3 & $2,61-3,40$ & Cukup \\
4 & $3,41-4,20$ & Kurang \\
5 & $4,21-5,00$ & SangatKurang \\
\hline
\end{tabular}

\section{HASIL DAN PEMBAHASAN}

Adanya Covid-19 sangat berpengaruh terhadap turunnya daya beli konsumen sehingga otomatis mempengaruhi pendapat UMKM yang ada di Bali khususnya di Kota Denpasar. Selain itu strategi konvensional yang digunakan para UMKM juga mempengaruhi sehingga mengakibatkan belum siapnya untuk menghadapi krisis. Dimana mereka masih mengandalkan strategi pemasaran dengan membuka gerai maupun menitipkan produknya di gerai, sehingga akibat dari kebijakan protokol kesehatan menyebabkan calon konsumen tidak mengunjungi gerai-gerai tersebut dan produk UMKM tidak dilirik di masa pandemi ini. Kebijakan pemerintah untuk Pembatasan Sosial Berskala Besar (PSBB) dan Physical Distancing mempengaruhi model bisnis yang berubah dari konvensional menjadi digitalisasi dengan mengubah model jual beli dengan memanfaatkan teknologi.

Dengan adanya kondisi tersebut, diadakannya PIP diharapkan dapat memberi motivasi riil dan stimulus bagi para UMKM di Kota Denpasar. Kegiatan PIP yang pertama kali diadakan oleh Pemerintah Kota Denpasar ini meliputi kegiatan workshop berbagai bidang usaha secara online, pendanaan usaha dan pendampingan usaha itu sendiri.

Tabel 2.

Distribusi Responden Berdasarkan Ilmu yang Didapatkan dari PIP

\begin{tabular}{llcl}
\hline No & Indikator & Skor & Kategori \\
\hline 1 & Modalusaha & 3,47 & Baik \\
2 & Ilmu bisnis & 3,85 & Baik \\
3 & Ide kreatif & 3,92 & Baik \\
4 & Jaringanusaha & 3,38 & Cukup \\
\hline
\end{tabular}

Sumber: Da ta diolah, 2021

Berdasarkan Tabel 2 didapatkan empat indiktaor pada variable PIP yakni Modal usaha (X1), Ilmu bisnis (X2), Ide kreatif (X3) dan Jaringan usaha (X4) serta 5 variabel Y yakni Peningkatan omzet penjualan (Y1), Peningkatan volume penjualan (Y2), Peningkatan jumlah pelanggan (Y3), Perluasan media pemasaran (Y4) dan Branding (Y5). Dari hasil perhitungan variable X, nilai tertinggi dilihat pada variable Ide kreatif (X3) dengan skor 3,92. Para UMKM yang lolos PIP ini mengakui bahwa kegiatan workshop sangat memberikan ide kreatif sesuai dengan bidang usahanya. Ide kreatif tersebut meliputi teknis pegemasan produk (packaging), teknik berjualan secara online (baik melalui social media ataupun market place), penggunaan bahasa marketing yang unik dan mudah diingat pelanggan, serta ide - ide lainnya yang mampu meningkatkan motivasi para UMKM dalam mengembangkan usahanya. Pada peringkat kedua variable Ilmu bisnis (X2) dengan skor 3,85 menunjukkan bahwa program ini mampu memberikan ilmu bisnis ter up to date yang bisa diterapkan dalam menyikapi bisnis di tengah pandemic. Kondisi yang tidak terduga bagi UMKM di Denpasar bahkan banyak usaha di dunia ini membuat para pelaku usaha harus mau belajar ilmu bisnis yang sesuai agar bisa tetap bertahan. Variable modal usaha (X1) dengan skor 3.47 menempati urutan ketiga karena program ini memberikan stimulus dana usaha bagi UMKM untuk menjalankan bisnisnya. Meskipun dana stimulus yang diberikan tergolong cukup rendah yakni Rp. 1.000.000.- per usaha, namun diakui bisa memberikan motivasi ekonomi bagi UMKM secara langsung. Pada variable $X$ terakhir yakni jaringan usaha (X4) dengan skor 3,38 didapatkan karena pada program ini para UMKM dilibatkan dalam 
kelompok pendampingan secara online dan offline di whatsapp group. Dalam kelompok tersebut para UMKM berdiskusi tentang profil usaha dan membetuk jejaring bisnis yang baru baik dari proses pengadaan nahan baku hingga proses pemasaran.

Hal ini menggambarkan bahwa persepsi masyarakat yang telah mengikuti PIP merasa bahwa materi yang diberikan oleh narasumber serta pendampingan yang dilakukan oleh para praktisi sudah cukup baik dan memberikan pengaruh positif terhadap keberlanjutan usahanya. Hal ini dapat dilihat dari pencapaian skor variable PIP yaitu sebesar 3,65 yang termasuk kedalam kategori baik.

Tabel 3.

Variabel Keberlanjutan Usaha

\begin{tabular}{llll}
\hline No & Indikator & Skor & Kategori \\
\hline 1 & Peningkatan omzet penjualan & 3,82 & Baik \\
2 & Peningkatan volume penjualan & 3,55 & Baik \\
3 & Peningkatanjumlah pelanggan & 3,28 & Cukup \\
4 & Perluasan media pemasaran & 3,25 & Cukup \\
5 & Branding & 3,47 & Baik \\
\hline
\end{tabular}

Sumber : Data diolah, 2021

Berdasarkan Tabel 3, didapatkan lima indikator pada variabel keberanjutan usaha dengan indikator tertinggi yakni peningkatan omzet penjualan (Y1) dengan skor 3,82. Terjadinya peningkatan omzet penjualan dirasakan para UMKM setelah satu bulan terlaksananya program pendampingan di akhir bulan januari. Indikator tertinggi kedua yakni peningkatan volume penjualan (Y2) dengan skor 3,55 yang sejalan dengan peningkatan omzet penjualan. Bentuk iklim usaha yang positif ini disebabkan dari pengembangan usaha yang lebih kreatif sehingga bisa menjangkau pangsa pasar yang sesuai dan lebih luas. Indikator tertinggi ketiga yakni branding (Y5) dengan skor 3,47 ditunjukkan dengan bertambahnya nilai branding berupa peningkatan penggunaan media social dan promosi usah a baik secara online dan offline.

Pada indikator keempat yakni peningkatan jumlah pelanggan (Y3) dengan skor 3,28 dilihat dari jumlah pelanggan baru secara offline, pangsa pasar baru bagi usaha kuliner yang mulai bekerjasama dengan aplikasi online (seperti go food dan grab food) dan peningkatan jumlah followers pada social media usaha. Pada indikator kelima yakni perluasan media pemasaran dengan skor 3,25 terlihat dari bertumbuhnya media pemasaran UMKM yang tidak hanya secara konvensional (dari toko offline) tapi juga merambah ke toko online yang tentunya bisa menjangkau lebih banyak pelanggan. Dari hasil tersebut, dapat diambil kesimpulan bahwa keberlanjutan usaha yang dimiliki oleh peserta PIP juga termasuk dalam kategori baik, dengan skor sebesar 3,48.

Hasil penelitian ini sejalan dengan penelitian Sirami Yanti, (2020) menyatakan bahwa pemerintah sangat beperan penting bagi keberlanjutan UMKM di daerah. Legalitas dan tatakelola sangat bergantung oleh kebijakan pemerintah daerah. Penelitian Nggara, et al (2021) menyatakan bahwa pemerintah melalui peraturan atau kebijakan yang telah ditetapkan sangat berpengaruuh terhadap segala sector, termasuk sektor UMKM.

\section{SIMPULAN DAN SARAN}

Berdasarkan pembahasan dan hasil analisis, kesimpulan yang didapatkan adalah persepsi peserta terdampak Covid- 19 terhadap PIP menunjukkan skor sebesar 3,66 yang termasuk kedalam kategori baik, sedangkan persepsi peserta terhadap keberlanjutan usaha mikro, kecil dan menengah di Kota Denpasar mendapatkan skor sebesar 3,47 yang juga termasuk dalam kategori baik. Saran yang bisa disampaikan kepada beberapa pihak meliputi pemerintah dalam hal ini Pemerintah Kota Denpasar dan UMKM yang telah mengikuti PIP. Untuk pemerintah disarankan agar melaksanakan prog ram ini secara berkesinambungan dan lebih menseleksi pendaftar agar peserta yang didapat sesuai dengan sasaran. Hail penelitian ini sesuai dengan tujuan penelitian ini adalah untuk mengetahui pengaruh Persepsi Peserta Pandemic Incubation Program Terhadap Keberlanjutan Umkm Di Kota Denpasar 
yang telah sesuai dengan penelitian - penelitian sebelumnya yang mendukung penelitian ini. Selain itu pemerintah juga diharapkan agar bisa mengalokasikan lebih tinggi dana stimulus yang diberikan dan membuatkan program lanjutan seperti kompetisi perkembangan usaha sebagai motivasi peserta yang sudah mengikuti program ini. Saran berikutnya untuk UMKM yang menjadi peserta PIP agar mengikuti program dengan sungguh - sungguh agar mendapatkan manfaat baik untuk bisnis ataupun personal. Para peserta juga disarankan agar menggunakan dana stimulus yang diberikan untuk usaha dan memanfaatkan pendampingan untuk memperluas jaringan pemasaran usaha.

Penelitian ini memiliki keterbatasan yaitu hanya menguji 2 variabel penelitian yang seharusnya dapat dikembangkan menggunakan variable - variable penelitian yang sejalan degan keberlanjutan UMKM pada saat pandemic Covid. Penelitian selanjutnya diharapkan dapat menambahkan variable, memperluas sampel penelitian.

\section{REFERENSI}

Ahmad, P. (2020). "Polemik Lockdown Di Tenga hegelisahan Ka um Marjinal. ADALAH 4.1.

Carlsson-Szlezak P, R. M. (2020). https://hbr.org/2020/03/what-corona virus-couldmean-for-the-globaleconomy. Retrieved from https://hbr.org/.

Ghozali, Imam. (2006). Aplikasi Analisis Multivariate Dengan Sess. Cetakan Keempat. Badan Penerbit Universita s Diponegoro. Semarang

Ghoza li,Imam. (2011). Aplikasi Analisis Multivariate Dengan Program IBM SPSS 19(Edisi Kelima). Semarang : Universitas Diponegoro

Gössling, D. S. (2020). Pandemics, tourism and global change: a rapid assessment of COVID-19. Journal of Sustainable Tourism. 29 (1), 1-20.

LPEM-FEB-UI. (2020). Dampak Pandemi Covid-19terhadap Pariwisata Indonesia: Tantangan, Outlook dan Respon Kebijakan. Retrieved from https://www.lpem.org/wpcontent/uploads/2020/04/Briefin g-NoteDa mpak-Pandemi-Covid-19-terhadapPariwisa ta-LPEM-UI-April-2020.pdf

Ngga ra, Darvolusius. Jayantini, I.G.A. Sri Rwa, Candra, Komang Dian Puspita. (2021). Persuasu ve Language Used in The Advertisements of Frankie Magazine. Elysian Journal, 1(3). 1-10.

Rianse dan Abdi. (2012). Metodologi Penelitian Sosial dan Ekonomi: Teori dan Aplikasi. Bandung: Alfa beta

Sirami Yanti, Ni Ketut Meliani, dkk (2020). Edukasi Sistem Produksi Dan Promosi Usa ha Arak B ali Di Desa Tianyar Barat Pada Masa Pandemi Covid-19. Prosiding Sminar Regional Pengabdian Kepada Masyarakat Unmas Denpasar Di Masa Pandemi Covid-19 Tahun 2020. 271-274.

Siregar, Sofyan. (2013). Statistik Parametrik Untuk Penelitian Kuantitatif. Jakarta: PT. Bumi Aksara

Somawati, A. V. (2020). Bali vs COVID-19: Book Chapters. Bali: Nilacakra.

Sugiyono. (2012). Memahami Penelitian Kualitatif. Bandung: Alfabeta.

Sugiyono. (2017). Metode Penelitian Kuantitatif, Kualitatif, dan R\&D. Bandung: Alfabeta, CV.

Tenenhaus, M., Vinzi, V.E., Chatelin, Y.M. and La uro, C. (2005) PLS Path Modeling. Computational Statistics \& Data Analysis, 48, 159-205.

Wina rno, Budi. (2002). Teoridan Proses Kebijakan Publik. Yogyakarta: Media Pressindo. 